\title{
REFLECTIONS ON VIOLENCE, GUNS, AND THE DEFENSIVE USE OF LETHAL FORCE
}

\author{
Daniel D. PolsbY*
}

\section{INTRODUCTION}

That individuals may legally employ lethal force under certain circumstances seems so intuitively obvious that it is seldom questioned. The proposition that a person suddenly attacked may defend himself is possibly understood simply as a codification of some paramount law of selfpreservation. A moment's reflection, however, will introduce doubt. First, self-preservation is not always paramount law. The law of duress, for example, excuses most crimes committed by a person who is himself under lethal compulsion, but does not excuse homicide. ${ }^{1}$ Soldiers who desert their posts under fire are not heard to plead the paramount law of selfpreservation, nor even, perhaps, is the proverbial starving man who filches a crust of bread; ${ }^{2}$ in such cases extenuating circumstances may be taken into account, if at all, only in connection with sentencing, not in determining guilt.

Second, even if self-preservation were paramount law, mutually exclusive claims for the right to invoke it could arise. ${ }^{3}$ An attacker who has initiated a lethal brawl only to find that he has bitten off more then he can chew might in the end have equally good practical reasons for invoking self-defense as would the person he attacked. Unless he managed to communicate successfully to

Copyright (C) 1986 by Law and Contemporary Problems

* Professor of Law, Northwestern University. Grateful acknowledgement is made to David Dranoff of the Illinois bar whose senior research project while a candidate for the J.D. degree at Northwestern University covered some of the ground discussed in this paper. Thanks are also due to the author's colleagues, Professors Kenneth Abbott, Ronald Allen, Mayer Freed, Victor Goldberg, John Heinz, Carol Rose, and Marshall Shapo, and to Professor Yale Kamisar of the University of Michigan law faculty, for their thoughtful criticisms of an earlier draft. Errors that remain are the sole property of the author.

1. See, e.g., Arp v. State, 97 Ala. 5, 9, 12 So. 301, 302 (1893); Watson v. State, 212 Miss. 788 , $792-93,55$ So. $2 \mathrm{~d} 441,443$ (1951).

2. This rule is given in $4 \mathrm{~W}$. Blackstone, Commentaries 31-32 (Philadelphia 1803 \& reprint 1965). Glenville Williams vigorously asserts that the criminal liability of the starving bread thief presupposes the existence of some nonlarcenous alternative, i.e., the availability of public or private charity. See G. Willitams. Criminal Law: The General Part 735-37 (2d ed. 1961). The .1/odel Penal Code adopts this argument under the rubric "Choice of Evils": "Conduct which the actor believes to be necessary to avoid a harm or evil to himself or to another is justifiable, provided that: (a) the harm or evil sought to be avoided by such conduct is greater than that sought to be prevented by the law: defining the offense charged . . . " Model Penal Code $\$ 3.02$ (Tent. Draft No. 8, 1958); acrord W. Lafave \& A. Scott, Criminal. Law $\$ 50$ (1972).

3. See Ryan, Self-Defense, Pacifism, and the Possibility of Killing. 93 Etrics 508, 510-15 (1983). 
his counterattacking victim an offer to stand down, however, the law would not allow the attacker to invoke the privilege, notwithstanding how personally urgent his need to defend himself might seem. ${ }^{4}$ What if he attacked a blind Korean karate master in a dark alley and then, discovering his bad luck too late, attempted to declare a cease-fire only to discover that his would-be victim had no way to understand him? From his own viewpoint, the attacker's equities would be no different than if he had successfully communicated surrender. Though the attack itself may have been wrong, at least he reconsidered and tried to do the right thing under the circumstances. From the viewpoint of the man attacked, however, the surrender not received is a nullity, and he would be under no duty to desist. Furthermore, if the defender sees or hears his attacker's offer of detente, and, nevertheless, fights on as if in a spirit of revenge, the attacker's privilege to defend himself revives. Though the attacker remains liable at least for a misdemeanor because of the original attack, ${ }^{5}$ he will not be guilty of any degree of murder if he must kill in self-defense; at worst he is guilty of manslaughter on the view that the self-defense privilege revives only incompletely. ${ }^{6}$

Another difficulty arises in trying to justify the lethal force privilege as simply an aspect of the paramount right of self-preservation. Someone who reasonably believes himself to be under threat of lethal attack has the privilege to respond with lethal force, whether or not his belief turns out to be correct. The contours of the privilege would be much more consistent with the idea of self-preservation if the self-defender were required to assume the risk of being wrong-the common law rule followed where lethal force was used by a civilian to prevent the escape of a fleeing criminal. ${ }^{7}$ Where defense of oneself from death or great bodily harm (or defense of a third person from such a perceived threat) is at issue, the cost of a reasonable mistake is to be borne not by the defender, but by the one whom he reasonably (although possibly mistakenly) believes to be his attacker. ${ }^{8}$

4. State v. Mayberry, 360 Mo. 35, 39-40, 226 S.W.2d 725, 727-28 (1950).

5. Wallace v. United States, 162 U.S. 466, $471-73$ (1896) (and cases cited therein); see Model Penal Code $\$ 3.04$ commentary at 21 (Tent. Draft No. 8, 1958).

6. See, e.g., Wallace v. United States, 162 U.S. 466, 471-73 (1896); Banks v. Commonwealth, 245 S.W. 296, 298 (Ky. 1922); Bausell v. Commonwealth, 165 Va. 669, 688-91, 18 I S.E. 453, 460-61 (1935); State v. Flory, 276 P. 458, 462 (Wyo. 1929). See generally W. LaFave \& A. Scott, supra note 2 , $\S 77$.

7. United States v. Hillsman, 522 F.2d 454 (7th Cir. 1975); Commonwealth v. Chermansky, 430 Pa. 170, 174, 242 A.2d 237, 240 (1968); R. Perkins \& R. Boyce, Criminal Law 1100 (3d ed. 1982).

8. In justifying homicide under such circumstances, perhaps the law is simply bowing to "the limits of the criminal sanction." People who believe that they are being attacked with deadly force are apt to respond without reference to whether the law threatens them with punishment if they are mistaken. Moreover, faced with a dead victim but a live defender a jury may acquit, thinking "there but for the grace of God . . . ." This explanation, however, proves too much. The same arguments for exoneration would apply (a) to the perpetrator who sincerely but unreasonably believes his life is in danger; (b) to one who has killed under duress; and (c) to the defendants in the notorious cases of The Queen v. Dudley \& Stephens, 14 Q.B.D. 273 (1884), and United States v. Holmes. 26 F. Cas. 360 (F.D. Pa. 1842). Yet such defendants are not exoncrated. Furthermore, it is surely true that at least some defenders might well be induced to stay their hands at least momentarily in order to make absolutely sure of their danger if the rule were that they would bear the cost of erroneous belief. 
There are circumstances in which the rule of reasonable mistake will be relatively uncontroversial. $X$ pulls a gun on $Y ; X$ knows the gun is not loaded and merely intends to frighten $Y$, but $Y$ does not know this fact and defends himself by pulling a gun of his own, which is loaded, and kills $X$. In this situtation, it might be said that $X$ brought about his own undoing ("got what was coming to him" or "assumed the risk"), but that argument cannot justify a reasonable mistake rule broad enough to apply even where a hapless innocent "got what was coming" to somebody else. Suppose $Y$ is holding off a mob at gunpoint and $X$, a police officer in plain clothes, approaches. Assuming that $Y$ reasonably mistakes $X$ for a member of the mob, and even though $X$ was behaving reasonably himself, if $Y$ shoots $X, Y$ will be guiltless. ${ }^{9}$ Similarly, if $Y$ is justified in shooting $X$ in self-defense, and the round passes through $X$ 's body and kills or injures $Z, Y$ will not be blamed. ${ }^{10}$

Even if we concede that in the above circumstances $Y$ should not be held for murder, we should still ask whether he should not on principle incur some sort of legal liability. Do we not want to give incentives to minimize the use of force where, in acting to protect what is his, $Y$ exposes to risk things that are not his?

The puzzle deepens upon consideration of the bumpy contours of the retreat rule. On its face the rule argues strongly for the self-preservation theory: in the minority of jurisdictions following it, a person threatened with a deadly confrontation must retreat if possible rather than respond with lethal force. " The requirement that retreat could apparently be made in complete ${ }^{12}$ safety probably rules out most sudden encounters with firearms, but could apply to many cases where knives, cudgels, and similar limited-range weapons are involved. Under the retreat rule, if $X$ pulls a knife on $Y$ in $Z$ 's saloon, $Y$ may use lethal force only if he is unable to retreat in complete safety and no nonlethal means of neutralizing the attack are reasonably available.

Even under the retreat rule, however, as between a householder and an intruder the privilege is not restricted ${ }^{13}$ as would be expected if it were simply an expression of the paramount concern for the preservation of life. Although the householder might avoid confrontation with complete safety, he

9. See Courvoisier v. Raymond, 23 Colo. 113, 120, 47 P. 284, 287 (1896).

10. Morris v. Platt, 32 Conn. 75, 84-89 (1864); cf. Cordas v. Peerless Transp. Co., 27 N.Y.S.2d 198 (1941) (taxicab driver, commanded to drive at gun point by a thief, was justified in jumping from the cab even though a pedestrian was injured on the sidewalk by the uncontrolled cab).

11. See Model Penal Code $\$ 3.04(2)(b)(i i)$ (Proposed Official Draft 1962); Restatement (SECOND) OF TORTS $\$ 65(3)$ (a) (1965).

12. The Model Penal Code adopts an even more restrictive formulation: the privilege to defend with deadly force does not arise if "the actor knows that he can avoid the necessity of using such force with complete safety by retreating." Model Penal Code $\$ 3.04$ (2)(b)(ii) (Proposed Official Draft 1962) (emphasis added). Compare this to the standard established in the Restatement: An actor may not use deadly force "if he comectly or reasonably beliezles that he can with complete safety avoid the necessity" of using "force intended or likely to cause death or great bodily harm" by means of retreat. Restatement (SfCOND) of ToRTs $\$ 65(3)$ (a) (1965) (emphasis added).

13. See Restatement (Second) of Torts $\$ 65(3)(\mathrm{a})$ (1965). For purposes of this discussion. "houscholder" means "a person in his own dwelling place which is not also the dwelling house of the [intruder]." Id. $\$ 65(2)(\mathrm{a})$. 
is not required to do so. ${ }^{14}$ Moreover, unless circumstances would make it manifestly unreasonable to do so, he is entitled to shoot the intruder without warning - to assume, in other words, that the intruder is dangerous, even if the householder cannot see that the intruder is armed in some way. ${ }^{15}$

Why the intruder may be killed is a vexing question. Burglary is no longer punished with death. Suppose the householder has a bulletproof bedroom door and access to a telephone, while the intruder is downstairs in the dining room. Why should the householder be allowed to court a potentially deadly encounter rather than be required to remain where he is in safety? Blood need not be shed, and in some cases, the intruder will be caught by police. Often, of course, he will not be caught, and in even fewer cases will he go to prison. Nevertheless, we certainly cannot mean to give the householder permission to make up for the defects of police work or the judicial process by allowing him to execute summary punishment on the intruder. Indeed, even if the householder does not have a bulletproof bedroom door and a telephone, there is no self-evident justification for subjecting the intruder to the risk of death by expediency where, with the full apparatus of due process, he would not risk death by punishment. ${ }^{16}$

14. Only a minority of American jurisdictions accept the retreat rule, however, while the majority allow a wronged person to stand his ground. See R. Perkins \& R. Boyce, supra note 7, at 1127-28. In majority rule states, self-defense is even less explicable by a rationale based on a paramount right to the preservation of life, for in these states innocent victims are never required to retreat-although they could do so in perfect safety-before responding in kind to a lethal threat.

15. [W] hen two people burglariously break into the premises of another, the person in rightful possession is not called upon to give any warning [before shooting]. There was force and violence used here in the act of breaking in, and defendant as a reasonable person had a right to assume that the two burglars were armed (although the evidence in this case shows that they were not) ...

Mitsu Nakashima v. Takase, 8 Cal. App. 2d 35, 38-39, 46 P.2d 1020, 1022 (1935); $f$. People v. Ceballos, 12 Cal. 3d 470, 479, 526 P.2d 241, 245-46, 116 Cal. Rptr. 233, 238 (1974) (burglary alone is not enough to justify killing; rather, the rightful possessor must reasonably believe that he is in danger of suffering great bodily harm or death); Cal. Penal Code $\$ 197$ (2) (West 1970) (homicide is justified in defense of habitation where the intruder has manifested an intention to commit a felony or to inflict violence on an inhabitant); Restatement (SECOND) of ToRTs \$ 143(2) (1965) (an actor may use deadly force to prevent a felony which is life-threatening or involves the breaking and entering of a dwelling); see also Tennessee v. Garner, $105 \mathrm{~S}$. Ct. 1964 (1985). Lethal weapons can be made surprisingly small, and need not leave a telltale bulge in outer clothing. United States v. Robinson, 471 F.2d 1082, $1117-18$ (D.C. Cir. 1972) (Wilkey, J., dissenting), rev d, 414 U.S. 218 (1973). Furthermore, a person need not be armed at all in order to pose a threat of death or great bodily harm to another. Imagine, for example, that the homeowner is an elderly invalid, and that the "intruder" is a group of five or six strapping teenagers.

Even the Model Penal Code seems to give the householder a broad dispensation to use deadly force against an intruder, although it tiptoes around the point by stating that before employing deadly force, the householder must believe that the intruder is attempting "arson, burglary, robbery, or other felonious theft or property destruction," and has "employed or threatened deadly force against or in the presence of the actor" or that "the use of force other than deadly force. . would expose the actor or another in his presence to substantial danger of serious bodily injury." MODEL PENal. Code \$ 3.06(3)(d)(ii) (Proposed Official Draft 1962). The use of the subjective standard here contrasts with the objective standard ("reasonably believed") of the RESTATEMENT (SECOND) OF TorTs $\$ 143(2)(1965)$.

16. See Discussion of Administration of the Criminal Law Tentative Draft . Do. 1. 9 A.I.I. Proc. 173, 187 (1931) (comments of William Mikell):

May I ask what we are killing him for when he steals an automobile and runs ofl with it?. . If we catch him and try him we throw every protection around him. . . . At most | |w $/$ give him 
Suppose the householder, hearing the intruder, retrieves his deer rifle from under the bed, creeps silently down the stairs, and draws a bead on the back of the intruder's head from a range of three meters. If the householder squeezes the trigger, the intruder will certainly be killed. If the householder does not pull the trigger, the intruder may: (1) escape, but no blood will have been shed; (2) detect the householder and surrender voluntarily; or (3) detect and attack the householder with his hands and feet, in which case (a) the householder may get the best of it, or (b) the intruder may get the best of it, without in either case any irreversibly serious injury occurring.

A fourth possibility is the one that seems to haunt the law: the intruder may be armed-many intruders are-or even if he is not armed he may be lethally dangerous. In such a case he may kill the householder, or otherwise inflict such damage that the householder, by common consent, would be justified in shooting. ${ }^{17}$ Yet, if murders are not unheard-of sequels to unlawful entries, neither are they especially common. Can the prevention of this unlikely horror seriously be thought to warrant the (hypothetical) certainty of the intruder being killed? The law of crime and punishment does not generally strike the balance between contingent harm and certain death so remorselessly. If the law had a general policy of killing people who might do things in the future more terrible than those done in the past, surely its hit list would have to include many people other than the intruder. But there is no such policy; at least where punishment proper is concerned, the retrospective idea of "deserving" serves as a boundary to the prospective idea of deterrence.

As these incongruities demonstrate, the law of lethal self-help certainly needs explanation. Quite clearly it bears no regular symmetry with the law of punishment or with the presumptions of innocence that the law of punishment provides. It grants a surprisingly broad right, but does not rigidly circumscribe that right with incentives to keep conduct as harmless as possible. Why not? An apology follows.

\section{The Right Way to Ask the Question}

If the analysis of the lethal force problem begins with questions about "deserving" such as "why should an apparently lethal attacker forfeit his life," the conclusion is most likely to be that, indeed, he should not. No American

three years in a penitentiary. Is it then for fleeing? . . Fleeing from an arrest is also a common law offense and is punishable by a light penalty, a penalty much less than that for stealing the automobile. If we are not killing him for stealing the automobile and not killing him for flecing. what are we killing him for?

17. This nightmare is older by far than the common law, for in the Tract Sanhedrin of the Babylomian Talmud the rule is given that "it is certain that a man cannot control himself when he seces his property taken"; "a burglar must have had the intention to kill anyone . . . who should oppose him"; and "if one comes to kill you, hasten to kill him first" 4 Babitontan Talmid). Tkacil SANHEdRIN 214 (Rodkinson trans. 1902). 
jurisdiction imposes (or may impose) ${ }^{18}$ the death penalty for a lesser crime than aggravated murder, and even when the death penalty is authorized, it is festooned with every imaginable procedural safeguard. By contrast, the private use of lethal force is a pure field expedient; the law expects mistakes to be made, and forgives them when they are reasonable.

When the problem is put in that way, the law seems all but indefensible; but perhaps it was the wrong way to formulate the problem. Suppose a police officer is attempting to make an arrest for some low grade of misdemeanorillegal fishing, for example-and the offender resists. The black letter rule is that the officer need not desist, although the crime is but a trivial one, but may press on to effectuate the arrest, escalating force as required. ${ }^{19}$ No one would describe this situation by saying that the officer has a right to kill a recalcitrant unlicensed fisherman. Rather, it is said, the officer is entitled to do his duty, and, if he is resisted, to defend himself from harm by minimally sufficient means. Asking why the unlicensed fisherman should forfeit his life or why he deserves to be killed misses the point: obviously he deserves no such thing. ${ }^{20}$ On the other hand, why should an offender, albeit a misdemeanant, have the power to veto an officer's efforts to perform a public duty? Does he in his mulishness "deserve" to be exempted from the effective reach of the law?

The right question to ask about lethal force rules, then, is not whether they apportion deserts properly within society. They do not and are not supposed to. A utilitarian question is better asked: Are lethal force rules calculated to keep the level of extreme violence in society to a minimum?21 At the very

18. See Coker v. Georgia, 433 U.S. 584 (1977).

19. Durham v. State, 199 Ind. 567, 574-75, 159 N.E. 145, 147 (1927) (arrest for illegal fishing); see also Model Penal Code $\$ 3.07$ commentary at 55-63 (Tent. Draft No. 8, 1958):

$[\mathrm{O}]$ ne justified in making an arrest is not obliged to desist because resistance is encountered. He may not only stand his ground but may press forward to achieve his object, meeting force with force, and if he believes that deadly force is necessary to protect himself, he may, of course, employ such force.

20. Indeed, even if the offender were apparently a mass murderer, he would not obviously "deserve" to be killed, even by the reckoning of one who in general had no qualms about capital punishment. Suppose the offender had just shot a roomful of people-in the presence of a police officer. Even though the offender is dangerous, it does not follow without more that he "deserves" to forfeit his life at the hands of the officer or even (eventually) at the hands of a hanging judge. He may be insane; he may have been laboring under a profound mistake of fact; he mav have been unbearably provoked. If any of these situations is true, even a hanging judge will not and probably may not treat the crime as capital. Yet if the officer, reasonably believing his life to be in danger and seeing that lesser measures are unlikely to be effective, shoots the offender, the law would not blame him and neither, surely, would the intuitive moral sense of the community.

21. In this connection it is interesting to consider what the contours of the deadly force privilege suggest about our traditional attitude toward less extreme violence. Our law differentiates extreme (i.e., deadly) violence from moderate (i.e., nondeadly) violence. The former is declared never to be a permissible means of defending against the infliction of the latter. Moderate violence, it seems, has acquired a curious sort of quasi-legitimacy. No matter how odious a bully and how inoffensive his victim, the latter is not to use deadly force, even if that is the only means available to avoid fighting. Of course, the bully may subsequently incur a penalty, usually a very light onc. But that comes only afterwards and is a matter between the bully and the state. In the meantime, however, his victim must fight and take his chances on a beating and humiliation if he is weaker or less skillful in the "manly art of self-defense."

Reflection suggests that a more peaceable society than the one in which we live might well take a much different view of the equities between the bully and the victim. 1he bully might secm 
least, if a rule could establish its credentials as the best peacekeeper, it should be presumptively accepted unless deontological arguments could carry the burden of persuasion on behalf of another, more acceptable rule. This is, after all, the way in which the always heated death penalty debate has largely been conducted.

The core argument of capital punishment abolitionists has always been that the death penalty is not a marginal deterrent to serious crimes. The violence of the death penalty would therefore be gratuitous, not useful. When Isaac Ehrlich claimed to trace a reduction in the homicide rate to the carrying out of executions, ${ }^{22}$ his work was attacked largely on methodological grounds. ${ }^{23}$ Detractors did not, as they might well have done, simply demur to Ehrlich's findings. ${ }^{24}$ The problem with such a demurrer, rather than a direct challenge to Ehrlich's conclusion, is that although the electric chair and the other utensils of capital punishment may be gruesome, murder is comparably gruesome; and if one gruesome act could be swapped for the other, the trade would be useful and might therefore seem acceptable. ${ }^{25}$

Most people get their information about the marginal deterrence of the death penalty in a very lawyerly way: they make it up. To some people, the marginal deterrence hypothesis for the death penalty seems intuitively obvious: "Death is clearly a steeper punishment than prison; raise the price of something-a crime-and you will affect marginal consumption." For others, the obverse seems equally intuitive: "There is no sense in using a rational choice model when the thing being chosen is an irrational act," or, much more cogently, "The probability of the penalty being inflicted is so small that it is unlikely to have a substantial present value even if a murderer were a rational calculator."

If the heavily studied and debated matter of the death penalty remains in a factual limbo, and therefore for many people in a moral limbo as well, it should hardly be surprising that the same is true of the lethal force problem, which has not attracted nearly as much attention. Here, as elsewhere, it is safe to say that people will make up their own answers to the question: what lethal force rule will produce the least amount of serious violence in society?

The following discussion examines two leading candidates. Under the first possibility, lethal force should never be allowed, even when it may be

monstrous in his abberational desire for fisticuffs, while the victim's desire to avoid fighting would be at once empirically normal and morally creditable. In such a society, the bully's very life might be counted as subordinate to the innocent victim's interest in avoiding violence; the latter might therefore be privileged to use deadly force rather than undergo the indignity of a brawl.

22. See Ehrlich, The Deterrent Effert of Capital Punishment: .t Question of liffe and Death. AM. Ecox. REv., June 1975, at 397.

23. See Zeisel, The Deterrent Effects of The Death Penalty: Facts 7. Faiths, 1976 Sup. Cr. Rry. 317. 329)36 (and sources citcd therein).

24. Drawing and quartering might be an even better deterrent to murder than the clectric chair. but its indecency undercuts its acceptability as a deterrent. Many people take the same position about the electric chair.

25. See Hook, The Death Senlence, in Tut: Death PrNaty in AMratca 146, 147 (H. Bedau ed. 1964). 
necessary for self-defense. This approach will be called the "no-violence" rule. The rationale for this rule would be roughly as follows: Defender cannot know with certainty whether attacker's apparently deadly intentions are real or only apparent; even if they are real, he cannot know with certainty whether they actually will carry forward to completion. On the other hand, defender has much more information about his own intentions (he knows whether he really will shoot or whether he is only bluffing); furthermore, he has more information about his own ability to carry on than he has about his attacker's ability (for example, he knows whether his own gun is loaded; he does not know whether his attacker's is). Given this mix of certainty and uncertainty, the violence-minimizing rule should simply forbid anyone to intend to inflict a potentially lethal wound. ${ }^{26}$

The other possibility is, roughly speaking, the law as it stands now, which allows lethal force under limited circumstances-basically, when there does not reasonably appear to be an alternative in connection with selfpreservation or when the alternative is the surrender of a duty (i.e., to enforce the law) or a right (i.e., to stand one's ground, in some states limited to one's home) that is sometimes paramount to the right to life itself. The argument favoring this rule is a bit more elaborate than the no-violence rule.

The no-violence rule says that, if no one resorts to violence, there will be no violence. Although fair as a syllogism, this statement is unsatisfactory in a world in which our capacity to produce outcomes by fiat is limited. The noviolence rule should address itself to the real world: what if most people, the law-abiders, repudiate violence, even in self-defense, but some people remain a bit violent and a few stay as violent as ever? Will there then be less violence overall?

Suppose there is a law forbidding people to use armed force to defend their homes against marauders. Will this rule affect the burglary rate ${ }^{27}$ (a) positively, by reducing the disincentive to burglaries, (b) negatively, as burglars internalize society's newly dramatized abhorrence of violence, or (c) not at all? An attempt must be made at least to try to imagine an answer to this crucial question and not to dodge it. The question is dodged by responding, "None of the above, because the householder can always secure himself by nonlethal means by, for example, rigging burglar alarms to all his doors and windows." That response is a dodge because, unless burglar alarms are calculated to arouse the attention of an armed police officer or

26. Appended to this argument, there would undoubtedly be the collateral submission that a nolethal-force rule would tend to inculcate peaceful behavior in society at large, teaching people that violence is never the answer (never mind what was the question). If the law is a potent teacher and people learn that lesson, then there should be less violence.

27. This assumes that burglary is a crime of violence, that is, that when put to it, a burglar will take by force or fear what he cannot take by stealth. It may be objected that burglars, as a class. Iry to avoid confrontation-that they are, in ideal form, nonviolent practitioners. Even if this objection were true, it would be irrelevant. Anyone who is made uncomfortable by this possibly mistaken assumption about burglars is invited to substitute "rapist" for "burglar," and "woman" for "homeowner"- and for that matter to substitute "any force" for "armed force" - to see whether it changes the argument. 
someone else who is prepared to deal with the intruder, the marauder will have little reason to care about alarms.

Given the present state of incomplete knowledge about human motivation, it is impossible to establish the probable effects of a no-violence rule empirically or to proffer nice dogmatic estimates of magnitude. ${ }^{28}$ Based on an LEAA-sponsored survey of convicts incarcerated in various prisons across the nation, an estimated 50,000 violent crimes may be deterred each year because of potential perpetrators' fears of encountering an armed victim. ${ }^{29}$ The difficulties in estimating the number of events not occurring, however, are obvious. So also are the difficulties in relying on surveys of convicted criminals (who, as a group, are remarkable neither for honesty nor acute introspection). Then there are the difficulties in extrapolating from their answers the attitudes of fellow criminals who, perhaps because of distinguishing characteristics such as greater shrewdness, have not been caught.

The fact that convicts themselves say that their behavior is influenced (that they are "deterred") by the possibility that their victim may be armed is significant. But moving from that point to the proposition that any particular number of crimes actually is deterred is another thing entirely. Self-defense rules cannot be compared to determine which produces a lower burglary rate and to what extent. No jurisdiction has adopted the no-violence rule; all allow the use of deadly force against a burglar in the home. Although a study of the nation's largest cities suggests that the jurisdictions most restrictive of private gun ownership have the highest robbery rates, ${ }^{30}$ explanations for this phenomenon other than deterrence by the prospect of victim self-defense are conceivable. For instance, it is reasonable to assume that many jurisdictions have adopted stringent gun control laws to combat existing high rates of violence. Conversely, jurisdictions with low violence rates will have felt much less pressure to ban guns. Many studies suggest, however, that-for whatever reason-gun control laws do not succeed in reducing violence. ${ }^{31}$ If these

28. Burglars appear to take into account the possibility of encountering armed resistance, and make their plans so as to avoid such confrontations. See Silver \& Kates, Self Defense, Handgum Ownership, and the Independence of Women in a Violent, Sexist Society. in Restricting Handguns 139, 151 (D. Kates ed. 1979) [hereinafter cited as Restricting Handguns]. See generally Kleck \& Bordua, The Factual Foundation for Certain Key Assumptions of Gun Control, 5 LAw \& POL'y Q. 271, 280-91 (1983).

29. See J. Wright \& P. Rossi, The Private Ownership of Firearms in the United States: Implications for the Criminal Justice System 10 (March 1984) (mimeograph) (available from Social and Demographic Research Institute, U. Mass., Amherst).

30. See Cook, The Effect of Gun Availability on Robbery and Robbery Murder: A Cross Section Sludy of 50 Cities, in 3 Pol'y Stud. Rev. AnN. 743, 776-78 (1979); see also Kates, Reflections on the Relezancy of Gun Control, 13 CRIM. L. Bull. 119,119 (1977) (citing five previous studies as demonstrating "that, taken together, the handgun-prohibiting jurisdictions have consistently higher homicide and violence rates" than demographically comparable ones that allow handgun ownership).

31. See DeZee, Gun Control Legislation: Impact and Ideology, 5 Law \& PoL'Y Q. 367 (1983); sep also Kates, supra note 30, at 119; Magaddino \& Medoff, An Empirical Analysis of Federal and State Fivearm Control Laus, in Firearms and Violence: Issues of Public Policy 225 (D. Kates ed. 1984). But spe National Institute of Justice, Weapons Crime and Violence in America: A Literature Reifiw and Research Agenda (1981) (enumerating the difficulties inherent in such cross-sectional studies). The National Institute of Justice authors concluded: "[T]here is some evidence that under some 
studies are correct, a correlation would naturally be expected to develop between high violence rates and gun prohibition laws, as well as between low violence rates and looser restrictions on firearms, both because people who are criminally inclined would not be deterred in the former case by the probability that their victims would be armed and because the behavior of such criminals is not much affected by gun prohibition. Dramatic reductions in criminal victimization have, of course, been observed in areas where potential victims' possession of guns has been given widespread publicity, but the number of examples is far too small for systematic study and persuasive conclusions cannot be drawn. The evidence now possessed is essentially anectodal, although it appears to suggest that crime rates vary with criminals' perceptions of the likelihood of meeting armed resistance as they ply their trade. ${ }^{32}$ Social science, in its conventional, empirical form, is likely to leave fastidious skeptics as skeptical as ever.

Even if strong arguments about the comparative results of direct experience cannot be made, there is nevertheless an argument-it would be premature to call it evidence-whose consideration may lead at least to a sense of where the burden of persuasion in this controversy ought to lie. This argument derives from game theory, which seems basically supportive of the existing complex of legal rules regulating the use of defensive lethal force. It suggests that a nonreciprocal no-violence rule, such as forbidding the use of lethal force even if necessary to self-defense, would produce incentives for more violence rather than less.

III

\section{Reciprocal CoOperation}

\section{A. Birds and Prisoners}

In The Selfish Gene, Professor Richard Dawkins invites us to imagine a world populated by five sorts of actors, differentiated solely by their different strategies concerning social aggression:

1. Hawks-who pick fights with anybody they encounter and, when they succeed in finding trouble, fight as hard as they can, withdrawing only if they are seriously injured.

2. Doves-who never pick fights but at most threaten, and who run away promptly if attacked.

3. Bullies-who act like hawks unless they are resisted, but who run away if their aggression is resisted.

4. Retaliators-who respond reciprocally: toward doves and other retaliators, they behave like doves; toward hawks they behave like hawks; they resist bullies but do not pursue them if they run away.

5. Prober-retaliators-who are like retaliators, except they occasionally experiment with hawkish behavior. ${ }^{33}$

conditions, reductions in gun related crimes can be achieved through gun control legislation. but this outcome will be neither very common nor especially pronounced." Id. at $\mathbf{5 4 1 .}$

32. The anecdotes are collected in Kleck \& Bordua, supra note 28.

33. R. Dawkins, The Selfish Gene $71-94$ (1976). 
The rules of this model world are as follows. First, none of the actors can identify beforehand who is a hawk, who is a dove, and so forth; each must discover the other's aggression strategy empirically. The success or failure of a strategy is determined objectively by its payoff according to an arbitrary system of scoring in which winning a confrontation yields 50 points, losing yields 0 points, being seriously injured yields -100 points, and wasting time over a prolonged confrontation yields -10 points.

Assuming this artithmetic, a population of all hawks or all doves is obviously "evolutionarily unstable," that is, an individual could find a deviant strategy with a higher average payoff than whatever strategy currently prevails. ${ }^{34}$ In an otherwise all-dove society a mutant individual (a hawk) with a deviant (hawkish) strategy will on the average lopsidedly outscore the nonmutant doves. The hawk will: (1) win every confrontation with a dove, (2) never be seriously injured, and (3) never be penalized for wasting time in confrontations, because doves will always run away when trouble begins. An all-hawk population is similarly unstable because, while almost every individual is busily wounding and being wounded and wasting time in unproductive fighting, a mutant with a dovish strategy will be piling up an advantage by at least avoiding injuries and wasted time.

Now let us modify this picture by imagining a large population of players, arbitrarily spread among all of the five aggression strategies described above. Thus, the various strategies are in round robin competition with one another. Will anything predictable happen? Put another way, is there a strategy which, once established, cannot be beaten by a deviant strategy? As it turns out, there is. According to Dawkins:

If all the five strategies I have mentioned are turned loose upon one another in a computer simulation, only one of them, retaliator, emerges as evolutionarily stable. Prober-retaliator is nearly stable. Dove is not stable, because a population of doves would be invaded by hawks and bullies. Hawk is not stable, because a population of hawks would be invaded by doves and bullies. Bully is not stable, because a population of bullies would be invaded by hawks. In a population of retaliators, no other strategy would invade, since there is no other strategy that does better than retaliator itself. ${ }^{35}$

The findings of Professors Robert Axelrod and William D. Hamilton ${ }^{36}$ are consistent with this argument. Based on game theory, they reason that interpersonal cooperation based on reciprocity can take hold in a community of asocial, nonaltruistic, selfish individuals. Their argument also involves round robin tournaments. In this scenario, the players are playing a twoperson game called Prisoners' Dilemma. Professor Douglas Hofstadter describes Prisoners' Dilemma as follows:

Imagine that you and an accomplice (someone you have no feelings for one way or the other) committed a crime; now you have both been caught and jailed and are apprehensively awaiting trials. You are being held in separate cells with no way to communicate with each other. The prosecutor offers each of you the following deal

34. See id. at 74; Smith \& Price, The Logic of Inimal Conflicts. 246 NATukf 15 (1973).

35. R. Dawkins, supra note 33 , at 80.

36. See Axelrod \& Hamilton. The Evolution of Cooperation. 211 Scinncr: 1390 (1981). 
(and tells you both that the identical deal is being offered to each of you-and that you both know it): "We have a lot of circumstantial evidence on you both. So if you both claim innocence, we'll convict you anyway and you'll both get two years in jail. But if you'll help us out by admitting your guilt and making it easier for us to convict your accomplice . . . we'll let you out free. [If you talk and he remains silent, he will be imprisoned for five years. But if you both admit your guilt,] you'll both get four year sentences. ${ }^{37}$

If each prisoner "cooperates" (with his accomplice, not with the prosecutor) so as to maximize their joint welfare, both will remain silent. It is stipulated, however, that neither prisoner has any interest in joint welfare maximization as such. Under these circumstances, which strategy should be chosen? Should one prisoner talk ("defect"), and gamble that the other will remain silent? Why should either prisoner expect the other to calculate differently from himself?

For a single bout of Prisoners' Dilemma, as it turns out, the correct strategy is always defection. ${ }^{38}$ If one considers, however, not one single faceoff but a series of round robins, where any one player is likely to encounter another given player in the future, the correct strategy is differentcooperation and reciprocity.

Professor Axelrod has demonstrated this result in two successive computer tournaments that put more than six dozen different Prisoners' Dilemma strategies into competition with one another. The brief description that follows quotes from Professor Hofstadter's discussion of this experiment. ${ }^{39}$ Imagine, says Hofstadter,

an ocean populated by dozens of little organisms swimming around and playing
Prisoners' Dilemma over and over with each other. Suppose each time two such
organisms encounter each other they recognize each other and remember how
previous encounters have gone. . . Now, if each organism is continually swimming
around and bumping into the others, eventually each one will have met every other
one numerous times and therefore all strategies will have been given the opportunity
to interact with one another. By "interact" what is meant is certainly not that any one
organism knocks any other one out of the ocean, as in an elimination tournament.
The idea is simply that each organism gains zero or more points in each meeting, and
if enough time is allowed to elapse, each organism will have met with every other one
about the same number of times, and now the only question is: Which organism has
amassed the most points?

In Axelrod's experiment,

the highest average score was attained by the simplest and [most analogous to "retaliator"] of all strategies submitted: TIT FOR TAT. This strategy is simply one of cooperating on the first move and [thereafter] doing whatever the other player did on the preceding move [i.e., the last time that particular player was encountered]. Thus TIT FOR TAT is a strategy of cooperation based on reciprocity. ${ }^{41}$

37. Hofstadter, Metamagical Themas, Scientific Am., May 1983, at 16, 16.

38. See Axelrod \& Hamilton, supra note 36, at 1392.

39. Axelrod's recently published book, R. Axelrod, The Evolution of CoOperation (1984), rehearses the argument in greater detail.

40. Hofstadter, supra note 37 , at 19 .

41. Axelrod \& Hamilton, supra note 36, at 1393. Professor Hofstadter lists as a few of the competing strategies the following: RANDOM (player cooperates or defects randomly); JOSS (player always responds to defection with defection, but responds to cooperation with cooperation 
Axelrod's experiment yielded results which he and Hamilton then subjected to "ecological analysis" for a series of future, hypothetical tournaments. Axelrod and Hamilton explain that the

ecological approach takes as given the varieties [of strategies] which are present and investigates how they do over time when interacting with each other. This analysis was based on what would happen if each of the strategies in the second round were submitted to a hypothetical next round in proportion to its success in the previous round. ... In the long run, TIT FOR TAT displaced all the other rules and went to fixation. ${ }^{42}$

\section{B. Stable Strategy and Lethal Force}

The foregoing discussion suggests that the no-violence rule would not diminish the amount of violence in society. If the Dawkins-Axelrod-Hamilton picture of aggression strategies bears any correspondence to the social world of human beings, the no-violence rule would actually increase violence. ${ }^{43}$ The no-violence rule's aim is to make law-abiding people into doves in a world where there are sure to be residual hawks and bullies. Or, to put it differently, by teaching a noncontingent rather than a reciprocal cooperation strategy, it allows noncooperators to make a profit. The perverse effect of the noviolence rule is that it rewards violence when practiced against those who obey the rule against being violent.

Do the arguments just recounted really have anything to say to the selfdefense problem? Whatever the resemblances, there are also some important formal differences. For example, the law does not allow the use of lethal force except reciprocally. Nor does it allow lethal force-or any force-for revenge: like the TIT FOR TAT strategist, a citizen is permitted to reciprocate his opponent's immediately previous move only. TIT FOR TAT does not allow the player to act on stale defections, nor does the law of self-defense allow a citizen to remember past attacks. ${ }^{44}$ Defections become "stale" in different ways, however, depending upon whether one is in a computer tournament or in real life. In the tournament, TIT FOR TAT requires that the opponent's last move be "reciprocated," however long ago it occurred; but if a man hits

only in a randomly selected $90 \%$ of cases); and TIT FOR TWO TATS (player cooperates with other player until other's second defection, then defects). Hofstadter, supra note 37, at 20, 22.

42. Axelrod \& Hamilton, supra note 36, at 1393 (footnote omitted). Professor Hofstadter's account of this "ecological analysis" is perhaps clearer than that of Axelrod and Hamilton:

[An ecological tournament] consists . . of an entire cascade of hypothetical replays [of Axelrod's second tournament], each one's environment determined by the results of the preceding replay. In particular, if you take a [strategy's] score in a tournament as a measure of its "fitness," and if you interpret "fitness" to mean "number of progeny in the next gencration," and finally if you let "next generation" mean "next toumament," then what you get is that each tournament's results determine the environment of the next tournament-and successful programs become more numerous in the next tournament. This type of iteratcd tournament is called ecological because it simulates ecological adaptation .

Hofstadter, supra note 37. at 24.

43. See R. Axelrod, supra note 39, at 184-86.

44. Past attacks may, however, be considered in determining whether a person was reasonable in believing there was a need to use protective force. Cf. Model. Penal. Codf $\$ 3.04(2)$ (b) (Official Drafi 1962). 
his neighbor first thing in the morning because the neighbor had hit him last thing the previous night, it would seem more like revenge than reciprocation. The question of what constitutes "reciprocal" behavior does not arise in the computer tournament; by hypothesis, a player has no uncertainty concerning a given opponent's move at their last encounter because that move is already completed when they meet again. The real world in which self-defensive privileges arise does not look like the game because the player is allowed to anticipate the opponent's next move as a substitute for reacting to his last one. If the law rigidly insisted that the game strategy of TIT FOR TAT be followed by one defending against deadly force, the defender's privilege to use lethal force would be conditioned upon his first being killed. The real world looks more like an elimination tournament, in which one player's move can remove any probability of encountering the other player later on. In such a case, reciprocity will not be a winning strategy. The real life adaptation of the winning strategy of the game, indeed, looks like it should be called "anticipatory TIT FOR TAT": the condition that must be met before the defender's privilege arises is an arrangement of circumstances that reasonably leads to the conclusion that, if a defender waited for TAT, he would probably run an unacceptably high risk of being killed. The Axelrod-Hamilton game is not played that way because it is a formal constraint of the game that the actors not have any information about other players' future intentions.

The anticipatory rule is a translation, not a transliteration, of the TIT FOR TAT rule into real life. It rests on the assumption that the capacity to foretell the very short-range future is an adequate substitute for awaiting the perfection of some harm. In other words, it supposes that the certainty of perfected action can be approached by anticipation when certain information is known. For example, a defender knows that someone who has just threatened him has a reputation for carrying a switchblade knife and is reaching into the back pocket of his blue jeans. Indeed, certain generalizations from experience (sometimes called "stereotypes") might satisfy the certainty requirement. For example, a defender knows from personal or vicarious experience that bug-eyed people with red faces and bulging veins on their foreheads who are smashing furniture, are dangerous. The question whether the required level of certainty had been reached in a given case-in other words, whether a defender's fears for his safety were "reasonable"-is the factual question that must be resolved in order to know whether a particular instance of defensive lethal force was privileged or not.

The retreat rule, where it is followed, might also be thought of as not corresponding to the reciprocal strategy, because (except in one's home) this rule forbids anticipatory reciprocal deadly force if escape is feasible. But the retreat rule exists much more in the books than in action, ${ }^{45}$ and even in the books it is hardly an imposing presence. According to the Restatement (Second)

45. See, e.g., People v. Williams, 56 Ill. App. 2d 159, 205 N.E.2d 749 (1965) (taxicab driver threatened while coming to aid of victim has right to stand his ground); $(f$. Kates \& Engberg. Deadly Force Self-Defense Agains/ Rape, 15 U.C.1). L. Rrv. 873, 904-05 (1982). 
of Torts, ${ }^{4 ;}$ for example, a self-defender outside his home has no right to meet deadly threats with deadly force if he "correctly or reasonably believes that he can with complete safety avoid the necessity of so defending himself . . . ."47 It is seldom possible to escape from firearms with complete safety, however, and as "[d]etached reflection cannot be demanded in the presence of an uplifted knife,"48 rarely would someone under deadly threat "reasonably" (but "incorrectly" - or correctly but unreasonably) see a way of escaping in complete safety, decide to stay and fight, and then be blamed for the consequences.

What of third-party injury? Neither the Restatement (Second) of Torts nor the Model Penal Code appears to condition the right to use defensive lethal force on innocent third parties being free from danger. Case law basically supports the notion that a defender is not required to take into account the probability of injury to third persons when the preservation of his own life from an intentional threat is at issue. ${ }^{49}$

Under the "paramount value of life" rationale, holding that third-party interests do not have to be taken into account seems anomalous. Even if for "balancing" purposes we could altogether disregard the value of the attacker's life, this still does not explain why the defender, in exercising his privilege, is allowed to expose many innocent people to a high-order risk of serious bodily harm. The defender is only one person. Allowing him to preserve himself does not "balance" the injury to a larger number of innocents. As we know from the famous case of The Queen $v$. Dudley $\mathcal{E}^{2}$ Stephens, 50 even a "cost justified" trade of a single innocent life for the lives of three "innocents" would not satisfy the legal arithmetic. Why should there be one result for "duress of circumstances" and another for self-defense, which is in many ways similar? The "balancing" idea does not explain what is apparently the law.

The game version of self-defense, however, is not seriously embarrassed by the law's apparent indifference to third-party injury. From the standpoint of the attacker, the question is whether he can profit somehow from adopting a strategy of attacking without provocation. If he can, he has an incentive to adopt such a strategy, and if he cannot, then he does not. From the viewpoint of the defender, the problem is to adopt a strategy that deprives the attacker of an incentive to attack. The presence or absence of third persons in the affray is irrelevant to him as well. ${ }^{51}$

46. As one would expect, the rule is the same in both tort and criminal law. See, e.g. State v. Cromwell. 72 N.D. 565, 9 N.W.2d 914 (1943); 1921 -1922 Nev. Att'y Gen. Biennial ReP. 127 ; 1982 Nev. Op. Atty Gen. 56.

47. Restatement (Second) of Torts $\$ 65$ (1965) (emphasis added); see also Model Penai. Code $\$ 3.04(2)$ (b)(ii) (Official Draft 1962).

48. Brown v. United States, 256 U.S. 335, 343 (1921).

49. See supra note 8 and accompanying text; see also People v. Matthews, 91 Cal. App. $3 \mathrm{~d} 1018$. 1024, 154 Cal. Rptr. 628, $631-32$ (1979).

50. 14 Q.B.D. 273 (1884).

51. Suppose the innocent is caught in the crossfire between the attacker and the defender? What is his privilege? Suppose he can end the gunfight and the danger to himself only by shooting the defender: may he do so? It is difficult to find a case in point, but it would seem that, in principle, 
If the defender's entitlement were based on an essentially personal interest, as was true in Dudley $\mathcal{E}$ Stephens, his injury of innocents would not necessarily be a matter of indifference-as it was not in Dudley $\mathcal{F}^{2}$ Stephens. It might be characterized as a sort of private "taking" by the defender, as to which the rule in situations involving the destruction of personal property has generally been that the defender must pay for the value of whatever he takes. ${ }^{52}$ But the crux of the rule in the game version of self-defense is the public policy of minimizing violence-a policy whose administration sometimes involves costs being borne by innocents. The innocents cannot seek compensation from the defender because the defender's privilege is grounded on public necessity ${ }^{53}$ rather than on his private interest in selfpreservation. Put differently, the innocent is "compensated" ex ante because the rule that allows his safety to be suddenly appropriated yields a world that is, on average, a safer place for him to inhabit.

The law of self-defense and lethal force, then, appears to show a preference for stable strategies. Reciprocal cooperation is such a strategy in the realm of games. With the real-world problem of life-threatening violence; however, there may be only more or less unstable strategies because to the extent that allowing anticipation insures uncertainty about whether a defender's actions are truly reciprocal, there is a risk of encountering a counterpoint of infinitely regressing anticipations between an attacker and a defender. In short, uncertainty makes anticipatory TIT FOR TAT a potentially bloody strategy, ${ }^{54}$ but this may be the best to be hoped for where lethal force is concerned. The reasonable fear of a person-whether attacker or defender-that he may be killed makes the situation like a one-shot game of Prisoners' Dilemma: the incentives for cooperation are not present and

the innocent should be so privileged and should not have to bear the risk of deciding correctly which of the two combatants was within his rights to be shooting. The answer might depend on whether the defender knew he was putting the innocent in harm's way by defending himself against the attacker. If the defender did know, it is difficult to see how the innocent's situation in respect to the defender is any different than the defender's position in respect to the attacker. Suppose the defender had inadvertently overlooked the innocent's danger, rather than deliberately deciding to sacrifice the innocent. This oversight would appear to put the innocent in the position of one who is threatened by another's negligence. There seems to be no clear answer to whether an innocent may defend against negligently created threats by using deadly force; the Restatement disclaims any position on the subject. See Restatement (Second) of Torts $\$ 66$ caveat (1965).

52. E.g., Vincent v. Lake Erie Transp. Co.; 109 Minn. 456, 124 N.W. 221 (1910) (tort action to recover value of damaged personal property).

53. Thus, for example, no compensation was given in United States v. Caltex (Philippines), Inc.. 344 U.S. 149 (1952), where the army had blown up a privately owned oil terminal in Manila during World War II to prevent its falling into enemy hands. Similarly, no compensation was given in Surocco v. Geary, 3 Cal. 70 (1853), where the Alcalde of San Francisco blew up plaintiffs building to build a brcak in front of a great fire. In contrast, a case like Vincent v. Lake Erie Transp. Co.. 109 Minn. 456,124 N.W. $221(1910)$, involved a chiefly private interest, albeit one in which the public has a collatcral stake (i.e., in preferring the least costly solution). No rule of law will "deter" the God who makes tempests in Iake Superior; the "game" in Iincent is entirely between a "defender" and an "innocent," and the problem is simply one of finding a rule that places the costs of the storm where they will be most sensibly borne. See, e.g., C. Morris \& C.R. Morris, Morris on Torts 40-42 (2d ed. $1980)$

54. Spe R. Axfi.rod, supra note 39, at 186; $f$. T. Schelling, The Strategy of Conflicts 207-09 $(1960)$. 
always-defect is the best and most stable strategy. One might, then, conjecture that in situations of nonlethal self-defense-the privilege of a person to defend against a barehanded attack by an evenly matched opponent-less anticipation would be required before the privilege could be invoked. Nonlethal confrontations seem to allow for the possibility of future cooperation between opponents, and thus leave room for reciprocity to be a winning strategy. A fistfight will not usually remove a player from the game of life, and a law that prefers stability ought to require that, compared with a lethal-force defender, a defender not under a lethal threat possess a greater amount of certainty that the harm he fears will actually come about, before he would be allowed to strike. ${ }^{55}$

The final question concerns which game strategy is violence-minimizing as between a householder and an intruder. This problem is the most difficult for game theory not only analytically, but also politically. It seems safe to assume that the class of intruders will be mostly male and will be younger, stronger, and more aggressive than the class of householders. The only practical way for a householder to dominate such an adversary is with firearms. Whether people should be allowed to possess firearms - and particularly handguns-in their homes for self-defense is, at present, a very lively political issue. If the violence-minimizing strategy in the homeowner-intruder confrontation is just what the present law allows-that the homeowner may shoot unless he has good cause to know that this action would be unreasonable, ${ }^{56}$ rather than only when he has good cause to know that this is reasonable-it would lead to a sort of natural law argument for a right to keep firearms in the home. ${ }^{57}$

The debate over banning the ownership of handguns or all firearms revolves around a number of asssumptions, of which three criminological ones are the most crucial. Advocates of prohibition assume (1) that banning guns will disarm people who would likely be subject to accidents, impulsive violence against relatives or acquaintances, the sudden onslaught of suicidal despondency, or a combination of these circumstances; ${ }^{58}$ and (2) that such

55. Even in nonlethal situations, however, a defender is not required to await the attacker's first blow before acting in defense. Prosser quotes the court in Chapleyn of Greye's Inn, Y.B. 2 Hen. IV 8, pl. $40(1400)$, explaining the defensive preemptive strike rule on the ground that "perhaps [defense] will come too late afterwards." W. Prosser, Law of Torts 109 (4th ed. 1971).

56. This privilege rests on the factual assumption that someone who breaks into another person's home is dangerous to the physical safety of the occupants. See Mitsu Nakashima v. Takase, 8 Cal. App. 2d 35, 38-39, 46 P.2d 1020, 1022 (1935). Whether the assumption makes sense is another matter, of course. and is discussed in the text infra at 107.

57. Such an argument is sketched out in Kates, Handgun Prohibition and the Original Meaming of the Second .tmendment, 82 MiCH. I. Rev. 204, 205 (1983).

58. I.ike the other elements in the super-heated gun control debate, this first assumption has inspired a substantial literature. Compare Edwards, Commentary: Murder and Gum Control, 18 Warne L. REV. 1335 (1972) and R. CIARK, CRIME IN AMERICA 108 (1970) (supporting the first assumption) with Kleck \& Bordua, supra note 28, at 280, 294 (")hus killings are rarely isolated outbursts of previously nonviolent people, but are usually a part of a pattern of violence, engaged in by lviolence-prone people]. . . Therefore, it is among violence-prone people that demand for guns is most inelastic, and it is they who would be the most likely to . . . violate gun laws . . . .). See also Bruce-Briggs. The (ireal Imerican Gum IIar, 45 PuB. INT. 37, 40 (1976) ("The great majority of |family homicides and accidents| are among poor, restless, alcoholic, troubled people, usually with long criminal records."). 
people will not substitute other weapons to equally lethal effect. ${ }^{59}$ Antiprohibitionists reject these assumptions and offer yet a third: that generalized gun ownership promotes self-defense and (approximating the subject matter of this discussion) deters criminal violence. If all three assumptions were granted, ${ }^{60}$ the value of banning firearms in reducing accidental fatalities, suicides, and domestic or acquaintance homicides might well outweigh the value of generalized firearm ownership as a deterrent to burglary, rape, robbery, and murder. Of course, that calculus would depend upon the orders of magnitude involved, a subject beyond the scope of this article. ${ }^{61}$

The present essay has the more modest aim of attempting to clarify some of the issues pertaining to the third assumption (self-defense as a means of deterring crime), and relating these issues to the first two assumptions in light of the principles that seem to underlie the law of deadly force in self-defense. Accordingly, it is appropriate to return to why the householder may automatically resort to deadly force when he finds an intruder on his premises. The answer cannot be that the householder is entitled to defend his property (or his home considered purely in its property aspect) with lethal force. Our law generally teaches that he is not so entitled, which is why

59. There can be little doubt that, overall, guns are per se more lethal than most other weapons that might be substituted if guns were not available to potential murderers and suicides. Thus, the validity of the second assumption becomes seriously questionable only in relation to proposals which (recognizing that rifles and shotguns are politically sacrosanct) contemplate the confiscation of handguns only. Kleck argues persuasively that a confiscation scheme so limited is downright counterproductive so far as the preservation of life and limb is concerned. See Kleck, Handgun-Only Gun Control: A Policy Disaster in the Making, in Firearms and Violence, supra note 31 , at 167 . Wound for wound, long guns are much more lethal than handguns (from which wounds the vast majority of victims recover). Id. at 195 . Even if handguns magically disappeared from the face of the earth, gunshot homicides would remain constant if there were substituted some lesser number of more deadly weapons. Based on lethality tables compiled from his analysis of a wide variety of commonly available rifles and shotguns, Kleck concludes that effective handgun confiscation would actually increase homicide rates if long guns were substituted in as few as $20 \%$ or more of the instances in which handguns are now used. Id. at 195-96. Kleck believes that the substitution rate would probably be much higher. Id. Accordingly, an effective handgun ban could be expected to increase substantially the rate of homicides from gunshot. Id. at 196-97.

In a similar vein, Kates argues that handgun-only firearms prohibitions could be expected to increase the death rates from shooting incidents. See Kates, supra note 57, at 261-64; see also Kates, Handgun Banning in Light of the Prohibition Experience, in Firearms and Violence, supra note 31, at 146.

60. Interestingly, all three assumptions were found unsubstantiated in an exhaustive analysis of pre-1979 studies and other literature by the Social and Demographic Research Institute of the University of Massachusetts. See National Institute of Justice, Weapons, Crime and Violence in America: Executive Summary i-ii (1981):

There is no compelling evidence that private weaponry is an important cause of, or a deterrent to, violent criminality. . . .

It is commonly hypothesized that much criminal violence, especially homicide, occurs simply because the means of lethal violence (firearms) are readily at hand, and thus, that much homicide would not occur were firearms generally less available. There is no persuasive evidence that supports this view:

Based on subsequent independent research of their own, Wright and Rossi have tentatively disavowed their negative evaluation of the third assumption. See supra note 29 and accompanying discussion.

61. For available sources of data as to the respective orders of magnitude of the values and costs of gun availability, see supra note 58. Such data are notoriously unreliable, and must be used gingerly. 
planting spring guns in unoccupied dwellings is regarded as illegal. ${ }^{62}$ The householder's privilege is limited to defending himself and others with lethal force, not his territory or his possessions.

Exercising the privilege under these circumstances must be based upon an assumption that the intruder is sufficiently likely to be armed or otherwise dangerous to justify his being shot on sight in the householder's premises. What is the basis of this assumption? Surely, empirically, a certain proportion of intruders are not dangerous, just as a certain proportion surely are. Nevertheless, it seems reasonable for the law to allow the householder to use deadly force against all intruders, at least where he is unable to distinguish the dangerous from the harmless. Assuming that the proportion of dangerous intruders is more than insignificant, there is little reason to balk at requiring all intruders to bear the costs of violence because without adding even a scintilla of anything valuable to the world, they have forced a dangerous or potentially dangerous situation on an innocent householder.

The intruder's dangerousness may simply reciprocate his entirely rational fear that the householder, in the exercise of his legal rights, will try to kill him. A rule that reduces an intruder's rational apprehension of being shot might reduce the number of dangerous intruders to insignificance (depending, of course, on the proportion of intruders who are going to be irrationally or sadistically violent). Truncating the householder's use of deadly force probably would, by reducing one of the occupational hazards of housebreaking, lead to more burglary, and thus reduce the caution housebreakers now take to strike only when they believe dwellings are unoccupied. ${ }^{63}$ More housebreaking would seem unavoidably to lead to more confrontations between intruders and householders. On the other hand, the danger of violence against householders associated with any given confrontation might be lessened if intruders considered themselves relatively safe from violence by householders.

Yet, would lessening the householder's privilege actually reduce the danger he represents to the rational intruder so as to persuade the latter not to attack? Although the householder, divested of his gun and his privilege to use it, might personally pose less of a threat to the intruder than he would with both gun and privilege, the householder still represents a threat that a rational intruder would surely respect. Depriving the homeowner of his gun or the privilege to use it (or both) will change the intruder's incentives to be violent only to the extent that it ultimately makes the intruder safer from the sort of harm that he might rationally use violence to avoid. The householder is, in other words, not at all in the same strategic position as Thomas Schelling's stylized confrontation between a householder and burglar who

62. See California v. Ceballos, 12 Cal. 3d 470, 526 P.2d 241,116 Cal. Rptr. 233 (1974); Katco v. Briney, 183 N.W.2d 657 (Iowa 1971); of. Posner, Killing or Ilounding to Protect a Property Imterest. $1+$ I. I. \& ECON. 201 (1971) (suggesting that the rule against spring guns to protect property rights is too pat and merely an artifact of the reality that there are usually less socially costly ways to protect property. than by setting deadly traps).

63. See supra note 28. 
care about only the problem of avoiding being shot by one another. ${ }^{64}$ The householder, even if he is unarmed and an invalid, almost always poses a substantial threat to the intruder because he might summon the police or subsequently identify the intruder. A policy that disarms householders, then, is one that contemplates (for the public good) placing a helpless person at the mercy of someone with a lethal motive. This policy is a step beyond the common law's apparent indifference to third-party injury: it does not merely place the safety of two innocents on an even footing, but also gives equal consideration to the safety of noninnocents. Indeed, it might be said to prefer the security of a wrongdoer to that of his victim.

In order to know what the violence-minimizing rule is as between the householder and the intruder, a definition of what constitutes violence and its different grades is necessary. The rule may also need differentiation of the grades by ordinal dignities and cardinal values. Even if there were a methodology reaching these problems, a thorny empirical question still exists: What are the facts? How many intruders would respond, one way or the other, to the incentives created by the privilege and the means to use it?

Explication of the householder's privilege could define home intrusion as a sort of violence equivalent to the first use of deadly force, thereby triggering reciprocal behavior by the homeowner. The definition seems strained, however, and might be improved by restating it: one who breaks into a dwelling, knowing it may be occupied, is so likely to be dangerous that the fact of breaking in can be taken as raising a presumption that he is dangerous. (Whether this statement is correct, of course, is in principle subject to investigation.) For the sake of comparison, accidents and impulsive domestic gunplay may also be defined as "violence." How should accidental hazards be traded with criminal ones? As an ordinal matter, there ought to be an answer to this question; if there is any force in Justice Holmes's maxim that even dogs distinguish between being stumbled over and being kicked, a given incident of criminal violence ought to be absolutely worse than an otherwise similar sort of accidental violence. ${ }^{65}$ A person ought to prefer being shot by mistake to being gunned down by a cold-blooded criminal, even though the wounds are the same. If this assumption is correct, it follows that, other things being equal, public policy ought to be willing to embrace gun ownership if it significantly deters contract murders and murders committed by rapists, robbers, burglars, and their ilk even though such a policy tends pari passu to increase the number of impulsive murders, accidental fatalities, and suicides.

64. See T. Schelling, supra note 54 , at 207-29.

65. Some support for the conjecture in the text may be found in Bureau of Justice Statistics. U.S. Dep't of Justice, The Severity of Crime 2 (1984), where it is reported that questionnaire respondents considered an intentional injury resulting in the victim's death as far more serious than a reckless injury resulting in death-a very interesting finding in view of the moral equivalence that the law often finds in reckless and intentional misconduct. The survey is a part of a study conducted by Marvin E. Wolfgang and Robert M. Figlio of the Center for Studies in Criminology and Criminal Law, Wharton School, University of Pennsylvania. The methodological underpinnings of this study were not available at the time of this writing. Accordingly, any claims that the Wolfgang-Figlio results strongly underwrite the conjecture must be, at best, muted. 
What if a very large number of the latter are being facilitated and only a very small number of the former are being deterred? In order to strike the balance, there is a need to have some idea of the difference between the order of magnitude of the crimes being deterred and of the crimes and accidents being facilitated. ${ }^{66}$ Reasonable people could differ about the balancing of these factors, but only within limits. For instance, arguing against the propriety of laws prohibiting the carrying of firearms outside the home except by those who qualify for a permit is difficult. Even if allowing everyone to carry arms at all times resulted in a negligible rate of acquisitive crimes, public security would probably be very close to negligible too, as drug addicts, alcoholics, paranoids, and persons with plain bad judgment or bad luck engaged in constant gun battles provoked by innocent mistakes, irrational delusions, or the knowledge that anyone who seemed to be acting erratically or aggressively was probably armed as well.

The range of innocent error between a householder and an intruder, however, will be much less. The householder possesses a crucial extra piece of information about his adversary: that the intruder is (almost certainly) a felon upon whom, by virtue of his intrusion, the state would wish to practice a species of what an intruder would surely regard as violence-arrest, imprisonment, and in rare cases, killing-and who therefore has an incentive to be violent himself if it will help him to avoid apprehension.

In short, the intruder's incentive to be dangerous follows not from the fact that homeowners may be armed, but rather from the fact that the law will severely punish intrusions, making the removal of a confronting homeowner desirable (as the intruder sees it) whether the homeowner is armed or not. From the point of view of the intruder, aggression against the homeowner is, in a sense, reciprocation by anticipation-anticipation of the "violence" of a heavy legal penalty. By giving the homeowner the right to anticipate this anticipation, the rule of lethal force in defense of the home may embody the conclusion that giving the homeowner a lethal privilege will not change the drift of the intruder's incentives should there be a confrontation. The rule will, instead, make intrusion more costly and therefore less likely to occur,

66. Although a number of the following figures are only approximations, the respective orders of magnitude are: Gun Accidents: 1600 deaths in 1978. National InStitute of Justice, supra note 31 , at 292 (tables 8-11). National Safety Counsel figures cited by Kates, supra note 57, at 263, indicatc that $15.5 \%$, or about 250 , of these deaths each year involve handguns. Gun Suicides: 16,000 annually. National Institute of Justice, supra note 31, at 289 (tables 8-10). Gun Murders: The 13.000 figure given by the Federal Bureau of Investigation, 1979 Uniform Crime Reports, Crime in the United STATES (1980), is roughly typical. Approximately 10,000 of these murders are committed with handguns and approximately $12.2 \%$ involve friends and relatives of the perpetrator. Id. at 7-11. See also National. InSTITUTE OF Justice, supra note 31 , at $403 \mathrm{n} .3$ (indicating that the percentage of homicides committed by strangers or in the commission of felonies or both has steadily risen over the past 20 years and that domestic acquaintance homicides have decreased). Self-defense/deterrence: Wright and Rossi guess that 50,000 violent crimes per year are not attempted because of the deterrent effect upon the putative perpetrator of learning that the putative victim is or may be armed. See supra note 29 and accompanying text. More positively, they estimate that the total number of instances in which firearms are used in se!f-defense approximately equals the sum of the total of unlawful gun uses and gun accidents annually. See National. Institute of Justick., supra note 31 , al 255-56. 
resulting in a reduction of probable confrontations. The privilege to use deadly force against an intruder, then, simply gives a homeowner a right to respond with a rational anticipation concerning the probable behavior of one who has a rational motive to do him, the householder, in.

Not surprisingly, there is a variant of the earlier described game of hawk versus dove that bears a closer resemblance to real life than that game does and that raises substantially fewer complications, when transposed into the real world, about the substitution of anticipation for reciprocation. If to the game of hawk versus dove there is added the rule that every player is assigned a home "turf' that he will regard as his exclusive territory, the so-called "bourgeois" strategy, once it becomes established, will defeat all invasions by hawkish, or dovish, competitors. ${ }^{67}$ The bourgeois strategy, a version of "retaliator," simply requires that each player, when on his own turf, behave like a hawk, but in all other cases like a dove. A bourgeois player, in other words, automatically treats a territorial incursion as a defection by the other player and responds accordingly.

Broadly speaking, the law of self-defense is strikingly "bourgeois." The rule that gives householders an expansive privilege to attack intruders, when joined with the custom of allowing householders to keep firearms that make such attacks effective, makes every householder a potential hawk. Yet in a public place or when in another's territory, people are not, in most jurisdictions, allowed to carry arms. While the law does not always require people to retreat from lethal encounters, the rule that disarms them, if it is effective, will make adoption of a dovish strategy inevitable for most people.

The law may well have found its way to a set of rules that is consistent with the lowest level of violence that rules, by themselves, can provide. That a neo-Darwinian mechanism would apparently lead to about the same result lends substance to the hackneyed observation that "the law is a living organism," which not merely changes, but "evolves."

\section{ConCLUSION}

Studied cursorily, the law of self-defense and lethal force appears to contain more than a fair share of anomalies. On closer inspection, however, the ideas of reciprocity and cooperation that work in two-person games may, with appropriate modifications, serve to explain the general contours of the legal rule and the underlying morality upon which the law rests. Such arguments cannot be used very decisively in discussing legislative initiatives designed to increase public safety by restricing the private ownership of guns. The costs of accidents, brawls, and suicides are known while the benefits derived from any given level of civilian firearms possession are uncertain. If rational choice models can capture the central tendency of human behavior over time, however, some amount of private gun possession would probably

67. M. Davis, Game Theory 143-45 (rev. ed. 1983) (and authorities cited therein). 
be better than complete disarmament of homeowners (presuming we could accomplish this) simply from the perspective of keeping violence in the world to a minimum. Without knowing how to compare the value of criminal versus noncriminal injuries, however, it is impossible to be specific about where the line should be drawn in restricting the private possession of firearms. 
